Research Article

\title{
Comparative Chemistry of Propolis from Eight Brazilian Localities
}

\author{
A. A. Righi, ${ }^{1}$ G. Negri, ${ }^{2}$ and A. Salatino ${ }^{1}$ \\ ${ }^{1}$ Botany Department, Institute of Biosciences, University of São Paulo, São Paulo, SP, Brazil \\ ${ }^{2}$ Psychobiology Department, Federal University of the State of São Paulo, São Paulo, SP, Brazil
}

Correspondence should be addressed to A. A. Righi; adnerighi@gmail.com

Received 11 January 2013; Revised 18 March 2013; Accepted 19 March 2013

Academic Editor: Vassya Bankova

Copyright (C) 2013 A. A. Righi et al. This is an open access article distributed under the Creative Commons Attribution License, which permits unrestricted use, distribution, and reproduction in any medium, provided the original work is properly cited.

Propolis is a complex honeybee product with resinous aspect, containing plant exudates and beeswax. Their color, texture, and chemical composition vary, depending on the location of the hives and local flora. The most studied Brazilian propolis is the green (alecrim-do-campo) type, which contains mainly prenylated phenylpropanoids and caffeoylquinic acids. Other types of propolis are produced in Brazil, some with red color, others brown, grey, or black. The aim of the present work was to determine the chemical profiles of alcohol and chloroform extracts of eight samples of propolis, corresponding to six Brazilian regions. Methanol and chloroform extracts were obtained and analyzed by HPLC/DAD/ESI/MS and GC/MS. Two chemical profiles were recognized among the samples analyzed: (1) black Brazilian propolis, characterized chiefly by flavanones and glycosyl flavones, stemming from Picos (Piauí state) and Pirenópolis (Goiás state); (2) green Brazilian propolis, characterized by prenylated phenylpropanoids and caffeoylquinic acids, stemming from Cabo Verde (Bahia state), Lavras and Mira Bela (Minas Gerais state), Pariquera-Açu and Bauru (São Paulo state), and Ponta Grossa (Paraná state). The present work represents the first report of prenylated flavonoids in Brazilian propolis and schaftoside (apigenin-8-C-glucosyl-6-C-arabinose) in green propolis.

\section{Introduction}

Propolis is a resinous hive product containing bee secretions and plant resins. The wide diversity of plant species used by bees as resin sources for propolis production determines its chemical diversity. More than 300 constituents have already been identified [1], among which phenolic compounds such as flavonoids, phenolic acids, and phenolic acid esters have been reported as major constituents of propolis from the temperate zone [2].

The use of propolis with medicinal purpose dates back to $300 \mathrm{BC}[3]$ and has been extensively used in folk medicine in the east and the west for centuries. It has been established that propolis possesses a wide spectrum of biological activities, such as antibacterial $[4,5]$, anti-inflammatory $[6,7]$, antioxidant $[8,9]$, hepatoprotective [10], and antitumoral [11]. The medicinal properties of propolis are due to a large variety of substances of plant origin, acting alone and/or synergistically. The high medicinal value of many propolis constituents stimulates chemical studies also of the corresponding plant sources [12].

The classes of propolis constituents include fatty and phenolic acids and esters, substituted phenolic esters [13], flavonoids (flavones, flavanones, flavonols, dihydroflavonols, chalcones) [14-16], mono-, sesqui-, di-, and triterpenes, steroids, aromatic aldehydes and alcohols, and naphthalene and stilbene derivatives $[17,18]$. Propolis from temperate regions (poplar derived) contains mostly flavonoids, aromatic acids, and their esters [19]. Mediterranean propolis from Croatia, Algeria, Greece, and Cyprus has a poplar-type chemical profile, while samples from South Greece and Crete are rich in diterpenes [20]. Propolis from Taiwan and Okinawa contains prenylated flavanones as major constituents [21, 22], while propolis from Australia is rich in prenylated stilbenes [18]. Propolis from tropical regions contains a diversity of phenolics: prenylated cinnamic acid derivatives, flavonoids, polyprenylated benzophenones and lignans, and other classes of constituents [23]. 
Among tropical countries, Brazil has the widest chemical diversity of propolis types. Brazilian green propolis is the most abundantly produced and consumed, either internally or externally. It contains mostly phenylpropanoids, prenylated phenylpropanoids (e.g., artepillin C), and sesqui- and diterpenoids and is produced with material obtained from apices of Baccharis dracunculifolia (Asteraceae) [24]. Chalcones, pterocarpans, and other isoflavonoids are the main constituents of Brazilian red propolis, which depends on Dalbergia ecastaphyllum (Leguminosae, Faboideae) as the main resin source [25, 26]. Propolis produced in the Brazilian Amazon may contain predominantly polyprenylated benzophenones, probably derived from Clusia spp. [27]. While it seems certain that a specific species plays the role as the main resin provider, probably bees often use several plant sources for propolis production [28]. For example, Brazilian red propolis may contain isoflavonoids (from Dalbergia) and polyprenylated benzophenones (probably from Clusia) [25].

Notable differences are often found between propolis samples, not only from distant but also from nearby locations, and sometimes in the same locality. This holds either for European $[29,30]$ or green propolis [31-33], even restricting the analysis to samples of "typical" green propolis [34]. Among samples of green propolis there seems to be a gradual variation in the proportion of mevalonate-derived substances (terpenoids, including sesqui- and triterpenoids) and the typical shikimate-derived (phenolics, prenylated or not) compounds [34]. For example in the distributional area of Brazilian green propolis (Southeast Brazil) there are samples from different localities, some with deep green color, others dark, and others black; often, the green samples contain high level of phenolic compounds, while the dark and black ones contain mostly triterpenoids (unpublished observations).

Powerful chromatographic tools, such as HPLC-DADESI-MS $^{n}$ and GC/MS, are essential for the analysis of products comprising of complex mixtures, enabling the identification and quantification of their biologically active constituents [35]. The aim of this work was to characterize the chemical profile of samples from distant Brazilian localities, with the expectation to establish chemical affinities among the analyzed samples and detect constituents not commonly reported for Brazilian propolis.

\section{Material and Methods}

2.1. Propolis Sampling and Processing. Samples of propolis produced by Apis mellifera were obtained from eight Brazilian localities: Picos (state of Piauí, North Central Brazil) (black propolis), Cabo Verde (Bahia state, northeast) (green propolis), Pirenópolis (Goiás state, Central Brazil) (black propolis), Lavras and Mira Bela (Minas Gerais state, Southeast) (green propolis), Pariquera-Açu and Bauru (São Paulo state, southeast) (green propolis), and Ponta Grossa (Paraná state, south) (green propolis) (Figure 1). The samples were grounded with a mortar and pestle to a fine powder. Extracts were successively prepared in Soxhlet for $3 \mathrm{~h}$ with $5 \mathrm{~g}$ of each propolis sample, first with chloroform and then with methanol. Each extract was concentrated under reduced

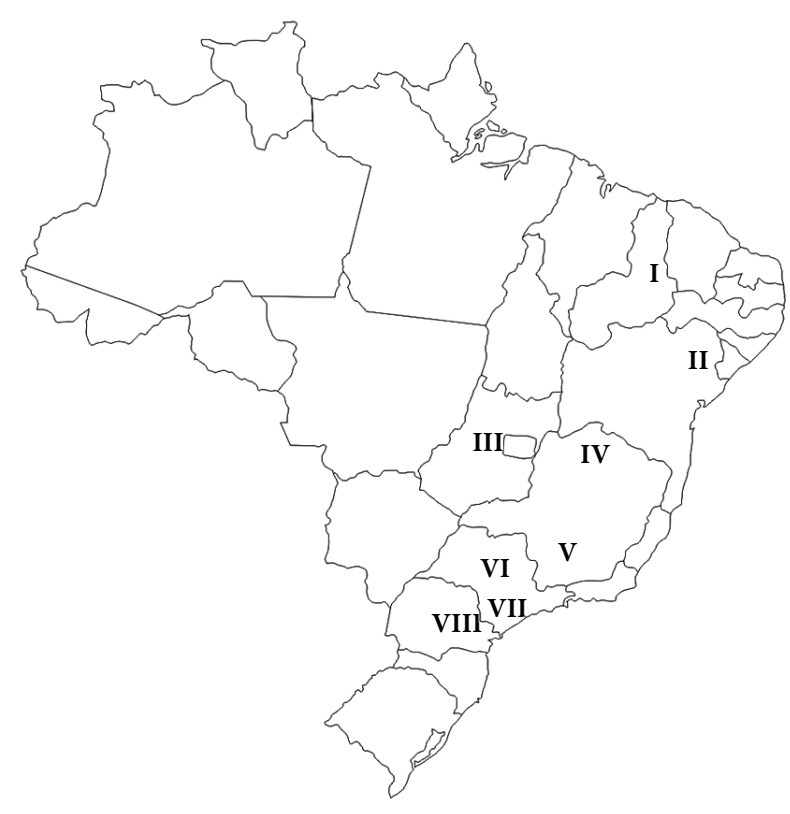

FIGURE 1: Brazilian map indicating the localities of the analyzed Brazilian propolis samples: I: Picos-PI; II: Cabo Verde-BA; III: Pirenópolis-GO; IV: Mira Bela-MG; V: Lavras-MG; VI: Bauru-SP; VII: Pariquera-Açu-SP; VIII: Ponta Grossa-PR.

pressure and the residue evaporated on a steam bath to constant weight. The chloroform extracts were dissolved in diethyl ether and treated with diazomethane [36]. The dried methanol extracts were dissolved in methanol at $0.1 \mathrm{mg} \mathrm{mL}^{-1}$ prior to HPLC analysis.

2.2. Total Polyphenol Contents. Total polyphenol contents were determined according to the Folin-Ciocalteu colorimetric method [37], using $p$-coumaric acid as reference. The analyses were carried out in triplicates of each sample.

2.3. Total Flavonoid Contents. Total flavonoid contents were determined by the aluminium chloride [37] and dinitrophenylhydrazin [38] methods. Calibration curves were made using quercetin (aluminium chloride method) and pinocembrin (dinitrophenylhydrazin method) as reference. Total flavonoid contents were assumed to be the sum of the values obtained by each method. Analyses were performed in triplicates.

2.4. GC/EIMS Analysis. The diethyl ether solutions of the diazomethane-treated chloroform extracts were diluted to the $1000 \mathrm{ppm}$ concentration. Ether solutions $(1 \mu \mathrm{L})$ of each extract was injected into a Hewlett Packard 5890 series II plus gas chromatography coupled to Chem Station System Mass Spectrometer 5989B operating with the EI mode at $70 \mathrm{eV}$. The GC conditions were as follows: DB-5HT fused silica capillary column $(30 \mathrm{~m} \times 0.32 \mathrm{~mm}$ internal diameter, $0.25 \mu \mathrm{m}$ film thickness) held at $100^{\circ} \mathrm{C}$ for $1 \mathrm{~min}$ and then heated to $300^{\circ} \mathrm{C}$ at $6^{\circ} \mathrm{C} \mathrm{min}^{-1}$, the final temperature being held constant for $2 \mathrm{~min}$; He was used as a carrier gas with flux of $1.5 \mathrm{~mL} \mathrm{~min}^{-1}$, 
TABLE 1: Contents of total phenols and flavonoids of samples of Brazilian propolis from localities in the states of Paraná (PR, south), São Paulo (SP, southeast), Minas Gerais (MG, southeast), Goiás (GO, Central Brazil), Bahia (BA, northeast), and Piauí (PI, central north).

\begin{tabular}{lcccc}
\hline \multirow{2}{*}{ Samples } & Total phenols (\%) & \multicolumn{2}{c}{ Flavonoids contents (\%) } & Total flavonoids (\%) \\
& & DNP method & AlCl $_{3}$ method & $5.432 \pm 0.002$ \\
Pirenópolis (GO) & $27.341 \pm 0.074$ & $0.800 \pm 0.000$ & $3.158 \pm 0.002$ & $3.148 \pm 0.003$ \\
Cabo Verde (BA) & $25.867 \pm 0.045$ & $0.368 \pm 0.001$ & $2.131 \pm 0.000$ & $1.970 \pm 0.000$ \\
Bauru (SP) & $17.632 \pm 0.043$ & $0.360 \pm 0.000$ & $0.958 \pm 0.002$ & $0.859 \pm 0.001$ \\
Ponta Grossa (PR) & $12.892 \pm 0.022$ & $0.367 \pm 0.000$ & $0.740 \pm 0.000$ & $0.685 \pm 0.000$ \\
Lavras (MG) & $9.281 \pm 0.029$ & $0.407 \pm 0.000$ & $1.427 \pm 0.000$ & $1.243 \pm 0.001$ \\
Picos (PI) & $5.620 \pm 0.017$ & $0.323 \pm 0.000$ & $1.005 \pm 0.004$ & $0.884 \pm 0.004$ \\
Pariquera-Açu (SP) & $2.660 \pm 0.018$ & $0.280 \pm 0.000$ & $0.333 \pm 0.000$ & $0.311 \pm 0.000$ \\
Mira Bela (MG) & $0.910 \pm 0.005$ & $0.206 \pm 0.000$ & & \\
\hline
\end{tabular}

linear velocity of $63 \mathrm{~cm} \mathrm{~s}^{-1}$, total flow $77,3 \mathrm{~mL} \mathrm{~min}^{-1}$, and split mode and solvent cut time of $3.0 \mathrm{~min}$. The MS conditions were as follows: ionization voltage, $70 \mathrm{eV}$; filament current, $0.3 \mathrm{~mA}$; detector voltage, $-0.7 \mathrm{kV}$; MS scan range, $40-800 \mathrm{~m} / z$. Injector and detector temperatures were at $300^{\circ} \mathrm{C}$. The characterization of the constituents was based on comparison of corresponding mass spectra with data from the libraries Wiley-275 (Hewlett Packard), Wiley/NBS, and McLafferty and Stauffer [39].

2.5. HPLC/DAD/ESI/MS Analysis. Methanol extracts $(10 \mu \mathrm{L})$ were analyzed by HPLC/DAD/ESI/MS and HPLC/DAD/ ESI/MS/MS. DAD SPD-M10Avp Shimadzu equipped with a photodiode array detector coupled to Esquire 3000 plus, Bruker Daltonics mass spectrometer via an electrospray ionization (ESI) source. The analyses were controlled by a computer running the Esquire NT Software from Bruker Daltonics. The diode-array detector was set at $270 \mathrm{~nm}$, and the online UV spectra were recorded in the range of 250$360 \mathrm{~nm}$. A reverse phase C18, Zorbax-5B-RP-18 (Hewlett Packard) column $(4.6 \times 250 \mathrm{~mm}, 5 \mu \mathrm{m})$, and different linear gradients were used for analysis of each sample. The mobile phases consisted of eluent A ( $0.1 \%$ aq. HOAc) and eluent $\mathrm{B}$ (methanol). For the Ponta Grossa sample, the following gradient program was used: $0 \mathrm{~min}, 5 \% \mathrm{~B} ; 10 \mathrm{~min}, 10 \% \mathrm{~B}$; $16 \mathrm{~min}, 30 \% \mathrm{~B} ; 72 \mathrm{~min}, 86 \% \mathrm{~B}$. For the Picos, Pirenópolis, Lavras, Bauru, and Pariquera-Açu samples the following program was used: $0 \mathrm{~min}, 10 \% \mathrm{~B} ; 12 \mathrm{~min}, 35 \% \mathrm{~B} ; 27 \mathrm{~min}$, $38 \% \mathrm{~B}$; $50 \mathrm{~min}, 50 \% \mathrm{~B} ; 100 \mathrm{~min}, 100 \% \mathrm{~B}$. For the Cabo Verde sample, the program was $0 \mathrm{~min}, 10 \% \mathrm{~B} ; 12 \mathrm{~min}, 20 \% \mathrm{~B} ; 52 \mathrm{~min}$, $40 \%$ B; 75 min, $86 \%$ B. For the Mira Bela sample, the program was $0 \mathrm{~min}, 5 \% \mathrm{~B} ; 10 \mathrm{~min}, 10 \% \mathrm{~B} ; 16 \mathrm{~min}, 34 \% \mathrm{~B} ; 60 \mathrm{~min}$, $78 \% \mathrm{~B}$. The flow rate was $0.5 \mathrm{~mL} \mathrm{~min}^{-1}$ and the temperature of the column was maintained at $28^{\circ} \mathrm{C}$. Negative-ion ESI was performed using an ion source voltage of $-40 \mathrm{~V}$ and a capillary offset voltage of $4500 \mathrm{~V}$. Nebulization was aided with a coaxial nitrogen sheath gas provided at a pressure of $27 \mathrm{psi}$. The dry gas temperature was set to $130^{\circ} \mathrm{C}$ and a dry gas flow of $4 \mathrm{~L} \mathrm{~min}^{-1}$ was used. Desolvation was assisted using a counter current nitrogen flow set at a flux of $7.0 \mathrm{~L} \mathrm{~min}^{-1}$ and a capillary temperature of $320^{\circ} \mathrm{C}$. Mass spectra were recorded over the range $50-900 \mathrm{~m} / z$. Mass spectrometry (MS/MS) data were acquired in the negative ionization mode. Compounds were identified by comparison of their UV and ESI/MS and ESI/MS/MS spectra with the literature data.

2.6. Clustering Analysis. Compounds identified by GC/MS and HPLC/MS of all eight propolis samples were analyzed using the neighbor-joining method and the software PAUP v.4.0b10 [40].

\section{Results and Discussion}

A wide variety of total phenols $(0,9 \%$ to $27,3 \%)$ and total flavonoids ( $0,3 \%$ to $4,4 \%$, Table 1$)$ were observed. It is known that the amount of phenolic and flavonoid constituents varies widely according to propolis types and seasonal factors [24, 28]. The highest amounts of both total phenolic substances and flavonoids were obtained with propolis from Pirenópolis (27.341\% and $4.432 \%$, resp.) and Cabo Verde $(25.867 \%$ and $3.148 \%$, resp.) (Table 1 ). The main constituents found in the Pirenópolis sample were flavone- $C$-glycosides, prenyl flavonols, and rhamnetin, while in the propolis sample from Cabo Verde only flavone-C-glycosides and a minor content of caffeoylquinic derivatives were detected. Samples from Bauru, Ponta Grossa, and Lavras have intermediate contents of total phenolics $(17.632 \%, 12.892 \%$, and $9.281 \%$, resp.) and showed the presence of caffeoylquinic derivatives, phenylpropanoids, and flavones. Finally, samples from Picos, Pariquera-Açu, and Mira Bela presented lower contents of total phenolics $(5.620 \%, 2.66 \%$, and $0.91 \%$, resp.) and higher caffeic acid glucoside. In South America, the contents of phenols reported for Brazilian propolis have been higher than the values obtained from samples of other countries: Argentina (0,3\%-5,5\%), Uruguay $(1,1 \%-3,7 \%)$, Chile $(1,1 \%-$ 4,3\%), Peru (less than $0,1 \%$ ), and Paraguay (0,3\%) [14].

On the other hand, samples from Bauru, Picos, PariqueraAçu, Ponta Grossa, Lavras, and Mira Bela showed low contents of total flavonoids: $1.97 \%, 1.243 \%, 0.884 \%, 0.859 \%$, $0.685 \%$, and $0.311 \%$, respectively. It is interesting to note that all samples, except from Bauru, present flavone $C$-glycosides among their constituents. However, only the mentioned sample exhibited high content of caffeic acid ethyl phenyl ester derivatives. Among the samples studied in the present work, there seems to be a direct correlation between the contents of total phenols and total flavonoids (Table 1). 
A high diversity of phenolic and nonphenolic substances was detected among the samples analyzed. Compounds 152 were present in less polar (chloroform) extracts and were detected and characterized by GC/EIMS analysis (Table 2). Several substances detected are wax constituents: long carbon chain fatty acids $(8,11,13,15,32$, and 34$)$ and $n$-alkanes $(33,36$, and 37$)$. Hydrocarbons and fatty acids have been pointed out as major constituents of wax propolis $[36,41]$. Other detected substances are phenolic compounds, many of them prenylated. Such substances have been pointed out as constituents of Baccharis dracunculifolia and/or Brazilian green propolis: 1, 3, 5, 9, 10, 14, 24, 25, 28, and 35 [12, 24, 42]. Compounds 3 and 14 (artepillin C) have been assigned the role as chemical markers of green propolis [12]. Terpenoids are frequent propolis constituents. Among them, diterpenoids $(\mathbf{1 7}, \mathbf{1 9}$, and 23$)$ have been reported for Brazilian propolis [43]. Triterpenoids $(\mathbf{4 0 , 4 3 - 5 2 )}$ are also frequent constituents of Brazilian propolis (see, e.g., [24, 42]). Steroids, such as ergosterol (42), are terpenoids rarely found in propolis. A particularly interesting compound in Table 2 is the glyceride 39, comprising of two residues of phenylpropanoid. Compounds such as this are constituents of Populus species and were obtained from a sample of Mexican propolis from the Sonora state [44], but the origin of 39 is certainly not a Populus plant.

Table 3 lists substances (53-133), mostly phenolic compounds, detected and characterized by HPLC/DAD/ESIMS. Caffeic acid (73) is very frequent in association with quinic acids or sugars. For example, in Table 3 several substances are caffeoylquinic acids, comprising of 1-3 residues of caffeic acid $(57,60,62,65,66,75,84,86,87,93,100,104,106$, and 107). Such compounds are characteristic and abundant constituents of green propolis, obtained ideally from aqueous extracts $[45,46]$. In some cases, one residue of caffeic acid is replaced by other phenylpropanoid, such as ferulic acid $(61,67,68$, and 113). In rare cases, quinic acid is esterified solely by ferulic acid (72). For the monocaffeoylquinic acids isomers, such as chlorogenic acids, the mass spectra in negative ion mode exhibited intense $[\mathrm{M}-\mathrm{H}]^{-}$ions at $\mathrm{m} / z$ 353.0 and some diagnostic fragments, due to caffeic $(\mathrm{m} / z$ 179) and quinic acid $(m / z 191)$ moieties $(57,60,62,66$, and 75$)$. $\mathrm{Di}-O-(E)$-caffeoylquinic acid positional isomers showed UV spectra identical to the monocaffeoylquinic acid derivatives and exhibited $\mathrm{m} / \mathrm{z} 515.0$ as deprotonated molecular ion, suggesting positional isomers of a quinic acid esterified with caffeoyl units at $m / z 179,191$, and 353 [M-H-caffeoyl] $]^{-}$ $(84,86,87,93$, and 104). Tricaffeoylquinic acid showed a deprotonated molecule at $m / z 677.1(65,106$, and 107). In general, tricaffeoylquinic acids with larger numbers of free equatorial hydroxyl groups in the quinic acid residue are more hydrophilic than those with larger numbers of free axial hydroxyl groups.

Glycosides are not frequent in propolis. Glycosides of caffeic acid (54, 58, and 59) have rarely (if at all) been reported as propolis constituents. $C$-glycosyl and $O$-glycosyl flavonoids were found in stingless bee honeys [47]. In the honey of Apis mellifera the contents of aglycone flavonoids typical of propolis (galangin, pinocembrin, quercetin) were found to be much higher than the contents of flavonoid glycosides. This has been attributed to a contamination of the honey by plant resins and propolis [48].

It has been recognized that flavonoids are not major constituents of Brazilian propolis, with the exception of isoflavonoids in red propolis [25]. Nonetheless, several flavonoid aglycones, as well as $\mathrm{O}$ - and $\mathrm{C}$-glycosides, were detected in several among the eight samples of propolis in the present work: 56, 64, 69-71, 74, 76-83, 88-92, 97-99, 101-103, 105, $108,109,111,114-116,118$, and 120-133. The glycosylation of flavonoids generally occurs at the 7-hydroxyl in flavones and at the 3- and 7-hydroxyls in flavonols. The sugars usually correspond to hexoses (glucose, galactose, and rhamnose) and pentoses (arabinose and xylose). The carbon-carbon bond of $C$-glycosyl flavonoids is resistant to rupture and consequently fragments from the sugar moiety predominate in the mass spectra of $C$-glycosides.

Flavone derivatives presented UV spectra with $\lambda_{\max }$ at 270.0 and $340.0 \mathrm{~nm}$. The ESI-MS spectra of compound 79 (vicenin-2) showed deprotonated molecule $[\mathrm{M}-\mathrm{H}]^{-}$at $\mathrm{m} / z$ 593.0. The MS/MS spectrum in the negative ion mode produced ions at $m / z 575.1[\mathrm{M}-\mathrm{H}-18]^{-}, m / z 503.0[\mathrm{M}-\mathrm{H}-$ 90] $]^{-}$and a base peak at $m / z 473.1[\mathrm{M}-\mathrm{H}-120]^{-}$, suggesting hexoses as sugar moieties. The fragment ions at $\mathrm{m} / \mathrm{z} 353.4$ [aglycone +83$]^{-}$and $m / z 383.2$ [aglycone +113$]^{-}$suggest that the aglycone is apigenin $(270)+$ glucose + glucose, according to the literature data $[49,50]$. The ESI-MS spectra of compound 81 (isoschaftoside-apigenin-8-C-glucosyl-6$C$-arabinose), and compound $\mathbf{8 8}$ (schaftoside-apigenin-6$C$-glucosyl-8-C-arabinose), showed identical deprotonated molecule at $\mathrm{m} / z 563.0$ and exhibited similar fragmentation patterns: $m / z 545.0[(\mathrm{M}-\mathrm{H})-18]^{-}, m / z 473.1[(\mathrm{M}-\mathrm{H})-90]^{-}$, $m / z 443.1[(\mathrm{M}-\mathrm{H})-120]^{-}, m / z 383.2$ [aglycone +113$]^{-}$, and $m / z 353.4$ [aglycone +83$]^{-}$. In addition, they yielded the ion $[\mathrm{M}-\mathrm{H}-60]^{-}$at $\mathrm{m} / z 503.0$, generated by the fragmentation of a pentose in the MS/MS spectra, suggesting the presence of an arabinose moiety $(-132 \mathrm{u})$, typical of asymmetric di- $C$ glycosylflavones. Isoschaftoside (81) showed a base peak at $\mathrm{m} / z 473$ and a high abundance of the fragment at $\mathrm{m} / z$ 503.0, indicating the presence of a 6-C-pentosyl unit [51].

For $O$-glycosylated flavonoids, fragmentation pathway starts with the cleavage of the glycosidic bonds and elimination of the sugar moieties, with charge retention on the aglycone [52]. Tentative identification was based mainly on the MS data, UV-DAD spectra, and literature data.

Compounds 83 (luteolin-O-glucuronide - $m / z$ 461.0) and 108 (apigenin- $O$-glucuronide $-m / z 445.1$ ) both underwent loss of a glucuronide moiety with $176 \mathrm{u}$. Compound 90 (pentosyl-orientin) yielded a deprotonated molecule ion at $\mathrm{m} / z 579.0$ and its MS/MS spectrum produced ions at $\mathrm{m} / z$ $327.0[\mathrm{M}-\mathrm{H}-(120+132)]^{-}$and the loss of $132 \mathrm{u}$ corresponding to a pentose moiety. This fragmentation pattern is typical of $\mathrm{O}$-glycosylated $\mathrm{C}$-glycosyl flavones [53], indicating a pentose $O$-linked to a $C$-linked glucose.

Compound 99 (dimethoxy-naringenin-diglucoside) exhibited UV maximum absorption at $280.0 \mathrm{~nm}$ and a deprotonated molecule ion at $\mathrm{m} / z$ 623.4. Its MS/MS analysis produced ions at $m / z 533.1(\mathrm{M}-\mathrm{H}-90.0)^{-}, m / z 503.1(\mathrm{M}-\mathrm{H}-$ $120.0)^{-}, m / z 413.1$ [aglycone +113.0 ], and $m / z 383.1$ [aglycone $+83.0]$. To our knowledge, this is the first report of this 
TABLE 2: Constituents from the chloroform extract of samples of Brazilian propolis, characterized by GC/EIMS.

\begin{tabular}{|c|c|c|c|}
\hline & Compounds & Rt (min) & Molecular ion \\
\hline 1 & 4-Vinyl phenol & 4.2 & $120\left(100, \mathrm{C}_{8} \mathrm{H}_{8} \mathrm{O}^{+}\right)$ \\
\hline 2 & Dihydrocinnamic acid methyl ester & 6.4 & $164\left(40, \mathrm{C}_{10} \mathrm{H}_{12} \mathrm{O}_{2}^{+}\right), 104\left(100, \mathrm{C}_{8} \mathrm{H}_{8}^{+}\right), 91(60)$ \\
\hline 3 & $p$-Vinyl-O-prenyl phenol & 9.7 & $188\left(50, \mathrm{C}_{13} \mathrm{H}_{16} \mathrm{O}^{+}\right), 133\left(100, \mathrm{C}_{9} \mathrm{H}_{9} \mathrm{O}^{+}\right)$ \\
\hline 4 & 2-T-butylnaphto-[2,3-b]-furan,4,9-dione & 13.5 & $254\left(30, \mathrm{C}_{16} \mathrm{H}_{14} \mathrm{O}_{3}^{+}\right), 239.0\left(100, \mathrm{M}-\mathrm{CH}_{3}\right)$ \\
\hline 5 & p-Hydroxycinnamic acid methyl ester & 13.5 & $\begin{array}{l}178\left(54, \mathrm{C}_{10} \mathrm{H}_{10} \mathrm{O}_{3}^{+}\right), 147\left(100, \mathrm{C}_{9} \mathrm{H}_{7} \mathrm{O}_{2}^{+}\right), 119\left(41, \mathrm{C}_{8} \mathrm{H}_{7} \mathrm{O}^{+}\right) \text {, } \\
91(60)\end{array}$ \\
\hline 6 & Methyl-O-benzoylbenzoate & 13.7 & $240\left(15, \mathrm{C}_{15} \mathrm{H}_{12} \mathrm{O}_{3}\right), 209(17), 163(100), 105$ (78), 77 (73) \\
\hline 7 & Benzene ethoxy & 13.8 & $122\left(13, \mathrm{C}_{8} \mathrm{H}_{10} \mathrm{O}\right), 105$ (16), 93 (70), $91(24), 79$ (32), 77 (21) \\
\hline 8 & $n$-Hexadecanoic acid methyl ester & 14.5 & $270(3)\left(\mathrm{C}_{17} \mathrm{H}_{34} \mathrm{O}_{2}\right), 143(12), 87(53), 74(100)$ \\
\hline 9 & Allyl-3-prenylcinnamate & 14.5 & $\begin{array}{l}256\left(64, \mathrm{C}_{17} \mathrm{H}_{20} \mathrm{O}_{2}^{+}\right), 201\left(84, \mathrm{C}_{13} \mathrm{H}_{13} \mathrm{O}_{2}^{+}\right), 185\left(100, \mathrm{C}_{12} \mathrm{H}_{9} \mathrm{O}_{2}^{+}\right) \\
157\left(60, \mathrm{C}_{12} \mathrm{H}_{13}^{+}\right), 145\left(95, \mathrm{C}_{11} \mathrm{H}_{13}^{+}\right)\end{array}$ \\
\hline 10 & $\begin{array}{l}\text { 2,2-Dimethylchromene-6-propenoic acid methyl } \\
\text { ester }\end{array}$ & 15.5 & $244(11), 229(100), 144(6)$ \\
\hline 11 & Palmitic acid & 16.4 & $256\left(5, \mathrm{C}_{16} \mathrm{H}_{32} \mathrm{O}_{2}\right), 241(8), 187(14), 121(51)$ \\
\hline 12 & Pinobanksin methyl ether & 16.6 & $286\left(\mathrm{C}_{16} \mathrm{H}_{14} \mathrm{O}_{5}\right)(10), 271(100)$ \\
\hline 13 & Oleic acid methyl ester & 16.7 & $296(1)\left(\mathrm{C}_{19} \mathrm{H}_{36} \mathrm{O}_{2}\right), 264(6)$ \\
\hline 14 & 4-Hydroxy-3-prenylcinnamic acid methyl ester & 16.7 & $246\left(70, \mathrm{C}_{15} \mathrm{H}_{18} \mathrm{O}_{3}^{+}\right), 191\left(100, \mathrm{C}_{11} \mathrm{H}_{11} \mathrm{O}_{3}^{+}\right), 171(20), 131(23)$ \\
\hline 15 & $n$-Stearic acid methyl ester & 17.2 & $298(1)\left(\mathrm{C}_{19} \mathrm{H}_{38} \mathrm{O}_{2}\right), 242(7), 143(18), 87(70), 74(100)$ \\
\hline 16 & Ferulic acid octadiene ester & 17.8 & $\begin{array}{l}302\left(20, \mathrm{C}_{18} \mathrm{H}_{22} \mathrm{O}_{4}\right), 287(40), 271(26), 257(13), 246(47) \\
231(76), 203(100), 187(83)\end{array}$ \\
\hline 17 & Methyl dehydroabietate & 17.8 & $314\left(8, \mathrm{C}_{21} \mathrm{H}_{30} \mathrm{O}_{2}\right), 299(10), 239(100), 141(14), 128(14)$ \\
\hline 18 & $n$-propyl- $P$-hydroxybenzoate & 18.2 & $180\left(5, \mathrm{C}_{10} \mathrm{H}_{12} \mathrm{O}_{3}\right), 161(11), 121(100), 105(18), 91$ (15), 77 (11) \\
\hline 19 & $\begin{array}{l}\text { 12,16-Epoxy-6-hydroxy-(15-16)-abeo-5,8,11,13- } \\
\text { abietatetraene-7-one }\end{array}$ & 18.2 & $312\left(17, \mathrm{C}_{20} \mathrm{H}_{24} \mathrm{O}_{3}\right), 241(5), 237(100), 197$ (25) \\
\hline 20 & Pentyl benzene & 18.6 & $148\left(16, \mathrm{C}_{11} \mathrm{H}_{16}\right), 133(23), 121(62), 105$ (51), $91(69), 77$ (50) \\
\hline 21 & Ferulic acid octene ester & 19 & $\begin{array}{l}304\left(29, \mathrm{C}_{18} \mathrm{H}_{24} \mathrm{O}_{4}\right), 271(22), 247(8), 246(100), 231(68), \\
199(23), 191(21), 187(42), 185(12), 131(36), 177(28), 131(36), \\
115(30), 105(14), 91(23), 77(19)\end{array}$ \\
\hline 22 & $n$-Phenyl hexadecane & 19.2 & $\begin{array}{l}302\left(9, \mathrm{C}_{22} \mathrm{H}_{38}\right), 287(10), 235(8), 175(31), 119(51), 105(61), \\
91(77), 77(63)\end{array}$ \\
\hline 23 & Ethyl dehydroabietate & 19.5 & $\begin{array}{l}328\left(25, \mathrm{C}_{22} \mathrm{H}_{32} \mathrm{O}_{2}\right), 268(9), 254(17), 253(100), 187(24), \\
156(12), 141(14)\end{array}$ \\
\hline 24 & $\begin{array}{l}\text { Hydroxy-diprenylcinnamic acid methyl ester } \\
\text { (artepillin C) }\end{array}$ & 20.6 & $\begin{array}{l}314\left(68, \mathrm{C}_{20} \mathrm{H}_{26} \mathrm{O}_{3}^{+}\right), 259\left(100, \mathrm{C}_{16} \mathrm{H}_{19} \mathrm{O}_{3}^{+}\right), 243\left(54, \mathrm{C}_{15} \mathrm{H}_{15} \mathrm{O}_{3}^{+}\right) \\
211(38), 203\left(90, \mathrm{C}_{12} \mathrm{H}_{11} \mathrm{O}_{3}^{+}\right)\end{array}$ \\
\hline 25 & $\begin{array}{l}\text { 2,2-Dimethyl-8-prenylchromene-6-propenoic } \\
\text { acid methyl ester }\end{array}$ & 20.7 & $312(14), 297(100)$ \\
\hline 26 & Pinobanksin-5-methyl ether acetate & 20.9 & $328\left(28, \mathrm{C}_{20} \mathrm{H}_{24} \mathrm{O}_{4}^{+}\right), 257(89, \mathrm{M}-71), 313(15)$ \\
\hline 27 & Benzoic acid, 4(4-hydroxybenzoyl)-methylester & 21.2 & $256\left(6, \mathrm{C}_{15} \mathrm{H}_{12} \mathrm{O}_{4}^{+}\right), 241(9), 161(12), 121(100), 147$ (11) \\
\hline 28 & $\begin{array}{l}\text { 3-Hydroxy-2,2-dimethyl-8-prenylchromane-6- } \\
\text { propenoic acid methyl } \\
\text { ester }\end{array}$ & 21.4 & $\begin{array}{l}330\left(100, \mathrm{C}_{20} \mathrm{H}_{26} \mathrm{O}_{4}^{+}\right), 297\left(30, \mathrm{C}_{19} \mathrm{H}_{21} \mathrm{O}_{3}^{+}\right) \\
272\left(50, \mathrm{C}_{17} \mathrm{H}_{20} \mathrm{O}_{3}^{+}\right), 225\left(60, \mathrm{C}_{15} \mathrm{H}_{13} \mathrm{O}_{2}^{+}\right), 197\left(50, \mathrm{C}_{14} \mathrm{H}_{13} \mathrm{O}^{+}\right) \\
171(50)\end{array}$ \\
\hline 29 & $\begin{array}{l}\text { Benzoic acid, } \\
\text { 2-propoxy-(4-hydroxybenzoyl)-methyl ester }\end{array}$ & 21.8 & $314\left(3, \mathrm{C}_{18} \mathrm{H}_{18} \mathrm{O}_{5}\right), 121(100), 109$ (21), 105 (25), 91 (30), 81 (47) \\
\hline
\end{tabular}


TABLE 2: Continued.

\begin{tabular}{|c|c|c|c|}
\hline & Compounds & Rt (min) & Molecular ion \\
\hline 30 & $\begin{array}{l}\text { Benzylic alcohol, } \\
\text { 2-propoxy-(4-hydroxybenzoyl)-methyl ester }\end{array}$ & 22 & $\begin{array}{l}316\left(4, \mathrm{C}_{18} \mathrm{H}_{20} \mathrm{O}_{5}\right), 301(4), 257(10), 189 \text { (22), } 147 \text { (10), } 121(100) \text {, } \\
105(26)\end{array}$ \\
\hline 31 & Benzoic acid, 2(4-hydroxybenzoyl)-methyl ester & 22.7 & 256 (10), 255 (50), 121 (100), 105 (33), 91 (44), 77 (35) \\
\hline 32 & $n$-Docosanoic acid methyl ester & 23 & $354(4)\left(\mathrm{C}_{23} \mathrm{H}_{46} \mathrm{O}_{2}\right), 87(70), 74(100)$ \\
\hline 33 & $n$-Heptacosane & 23.11 & $\mathrm{C}_{27} \mathrm{H}_{56}: m / z 380, \mathrm{C} 27$ \\
\hline 34 & $n$-Tetracosanoic acid methyl ester & 23.4 & $382\left(4, \mathrm{C}_{25} \mathrm{H}_{50} \mathrm{O}_{2}\right), 143(14), 87(60), 74(100)$ \\
\hline 35 & $\begin{array}{l}\text { 4-Dihydrocinnamoiloxy-3-prenylcinnamic acid } \\
\text { methyl ester }\end{array}$ & 24.7 & $\begin{array}{l}378\left(2, \mathrm{C}_{24} \mathrm{H}_{26} \mathrm{O}_{4}^{+}\right), 246\left(84, \mathrm{C}_{15} \mathrm{H}_{18} \mathrm{O}_{3}^{+}\right), 105\left(82, \mathrm{C}_{8} \mathrm{H}_{9}^{+}\right) \text {, } \\
91(100)\end{array}$ \\
\hline 36 & $n$-Nonacosane & 24.9 & $\mathrm{C}_{29} \mathrm{H}_{60}: m / z 408, \mathrm{C} 29$ \\
\hline 37 & $n$-Hentriacontane & 26.7 & $\left(\mathrm{C}_{31} \mathrm{H}_{64}\right): m / z 436, \mathrm{C} 31$ \\
\hline 38 & Carbomethoxy benzyl caffeate ester & 26.9 & $\begin{array}{l}328(60)\left(\mathrm{C}_{18} \mathrm{H}_{16} \mathrm{O}_{6}\right), 327(50), 285(40), 268(33), 207(40), \\
181(40), 150(40), 135(100), 115(40), 107(30), 105(30), 94(30), \\
91(45), 77(60)\end{array}$ \\
\hline 39 & Dihydrocaffeoyl-dihydrocinnamoyl-glyceride & 27.21 & $\begin{array}{l}430\left(9, \mathrm{C}_{23} \mathrm{H}_{26} \mathrm{O}_{8}\right), 399(9), 380(25), 281(25), 232(30), 180(25), \\
175(29), 161(100), 105(12), 95(11), 93(9), 81(16), 77(16)\end{array}$ \\
\hline 40 & $\beta$-Amyrin & 28 & $\begin{array}{l}426\left(16, \mathrm{C}_{30} \mathrm{H}_{50} \mathrm{O}^{+}\right), 408\left(\mathrm{C}_{30} \mathrm{H}_{48}^{+}\right), 218\left(100, \mathrm{C}_{16} \mathrm{H}_{26}^{+}\right) \\
203\left(40, \mathrm{C}_{15} \mathrm{H}_{23}^{+}\right), 189\left(25, \mathrm{C}_{14} \mathrm{H}_{21}^{+}\right)\end{array}$ \\
\hline 41 & Propyl carbomethoxy benzyl dihydrocaffeate ester & 28.1 & $\begin{array}{l}372\left(24, \mathrm{C}_{21} \mathrm{H}_{24} \mathrm{O}_{6}\right), 371(26), 357(70), 314(30), 299(30), \\
207(42), 167(30), 135(100), 107(50), 91(50), 93(50), 95(57), \\
77(69)\end{array}$ \\
\hline 42 & Ergosterol & 28.96 & $\begin{array}{l}396\left(16, \mathrm{C}_{28} \mathrm{H}_{44} \mathrm{O}\right), 381(26), 281(35), 232(35), 217(34), 207(19) \\
165(10), 164(27), 161(30), 151(39)\end{array}$ \\
\hline 43 & Lupenone & 29.5 & $\begin{array}{l}424\left(7, \mathrm{C}_{30} \mathrm{H}_{48} \mathrm{O}\right), 218(50), 205(100), 189(50), 177(50), 109(56) \\
105(24)\end{array}$ \\
\hline 44 & $\beta$-Amyrinone & 30.5 & $424\left(6, \mathrm{C}_{30} \mathrm{H}_{48} \mathrm{O}\right), 218(100), 205$ (60), 203 (40), 189 (23) \\
\hline 45 & $\alpha$-Amyrinone & 30.9 & 424 (6), 218 (100), 205 (60), 203 (20), 189 (23) \\
\hline 46 & $\alpha$-Amyrin & 31 & $426\left(6, \mathrm{C}_{30} \mathrm{H}_{50} \mathrm{O}\right), 411$ (15), 218 (100), 207 (90), 203 (18), 189 (24) \\
\hline 47 & $\beta$-Amyrin acetate & 31.6 & $468\left(1, \mathrm{C}_{32} \mathrm{H}_{52} \mathrm{O}_{2}\right), 218(100), 203(40), 189(45)$ \\
\hline 48 & $\alpha$-Amyrin acetate & 32.5 & $468\left(1, \mathrm{C}_{32} \mathrm{H}_{52} \mathrm{O}_{2}\right), 218(100), 203(20), 189$ (35) \\
\hline 49 & Taraxerone & 33.4 & 424 (4), 205 (80), 189 (76), 109 (74), 69 (100) \\
\hline 50 & Oleanene & 33.9 & $410(95), 395\left(100, \mathrm{M}-\mathrm{CH}_{3}\right), 174(40), 165$ (58) \\
\hline 51 & Pteron-14-en-7-one & 35.6 & $424(66), 409$ (100), $383(64), 371(56), 165(50)$ \\
\hline 52 & Olean-14-en-3,28-dione & 36.2 & $\begin{array}{l}440\left(30, \mathrm{C}_{30} \mathrm{H}_{46} \mathrm{O}_{2}\right), 425(100), 409(78), 397(76), 385(60), \\
183(75), 165(70)\end{array}$ \\
\hline
\end{tabular}

compound for propolis, having previously been identified from Citrus genotypes [54].

Among the constituents identified stand out the prenylated flavonols 109, 125, 126, and 128-133. Prenylated phenylpropanoids typical of Brazilian green propolis were also detected, such as compounds 95, 96, 117, and 119 (artepillin C).

The chemical affinities among the analyzed propolis samples are shown in Figure 2. One of the clusters of the dendrogram combines the samples from Bauru (SP, southeast),
Lavras (MG, southeast), and Cabo Verde (BA, northeast). It is somewhat surprising the emergence in this cluster of the sample from the latter locality, which is much up north from the commonly admitted distribution of green propolis. The three samples share several prenylated phenylpropanoids (e.g., 9, 14, 24, 25, and 35) typical of green propolis (Table 4). The sample from Cabo Verde stands apart in the clade for the more frequent possession of flavonoid glycosides, for example, 88-91, 98, 99, and 101 (Table 4). Flavonoids are major compounds in propolis from temperate 
TABle 3: Constituents from the methanol extract of Brazilian propolis from Paraná (south), São Paulo and Minas Gerais (southeast), Goiás (central), Bahia (northeast), and Piauí (central-north) states, characterized by HPLC/DAD/ESI/MS.

\begin{tabular}{|c|c|c|c|c|}
\hline Compound & $\mathrm{Rt}(\mathrm{min})$ & $\mathrm{UV} / \mathrm{DAD}$ & {$[\mathrm{M}-\mathrm{H}]^{-}$} & Proposed structure \\
\hline 53 & 4.9 & 270 & 181 & Homovanillic acid \\
\hline 54 & 5.5 & 300,330 & 341.2 & Caffeic acid 4-O-glucoside \\
\hline 55 & 5.7 & ND & 191.1 & Quinic acid \\
\hline 56 & 15 & 290 & 303.1 & Dihydroquercetin \\
\hline 57 & 16.1 & 330,300 & 353 & Caffeoylquinic acid \\
\hline 58 & 16.3 & 300,330 & 311 & Caffeic acid 4-O-arabinoside \\
\hline 59 & 19.5 & 300,330 & 311.2 & Caffeic acid 4-O-xyloside \\
\hline 60 & 19.6 & 300,330 & 353.1 & Caffeoylquinic acid \\
\hline 61 & 20.3 & 330,300 & 529 & Feruloyl-caffeoylquinic acid \\
\hline 62 & 20.4 & 300,330 & 353.3 & Caffeoylquinic acid \\
\hline 63 & 21.9 & ND & 183 & Methoxy-dihydroxy benzoic acid \\
\hline 64 & 22.1 & 270,340 & 475.5 & Dimethoxy-luteolin-glucoside \\
\hline 65 & 22.3 & 300,330 & 677.1 & Tricaffeoylquinic acid \\
\hline 66 & 22.3 & 330,300 & 353.5 & Caffeoylquinic acid \\
\hline 67 & 22.3 & 330,300 & 529 & Feruloyl-caffeoylquinic acid \\
\hline 68 & 22.7 & 330,300 & 529 & Feruloyl-caffeoylquinic acid \\
\hline 69 & 23.8 & ND & 607.3 & Methylkaempferol-O-rutinoside \\
\hline 70 & 23.9 & $280,330 \mathrm{sh}$ & 433.3 & Naringenin- $C$-glucoside \\
\hline 71 & 24 & 270,338 & 577.5 & Apigenin-O-rutinoside \\
\hline 72 & 24.3 & 300,330 & 367.5 & Feruloylquinic acid \\
\hline 73 & 24.9 & ND & 179.3 & Caffeic acid \\
\hline 74 & 25.2 & ND & 435.1 & Delphinidin arabinoside \\
\hline 75 & 25.7 & 330,300 & 353.3 & Caffeoylquinic acid \\
\hline 76 & 26.4 & ND & 421.2 & Catechin arabinoside \\
\hline 77 & 27.1 & 270,338 & 577.1 & Apigenin-di- $C$-glucosyl rhamnoside \\
\hline 78 & 27.4 & 270,338 & 415.3 & Apigenin- $C$-rhamnoside \\
\hline 79 & 27.7 & 270,338 & 593.1 & Apigenin-6,8-di- $C$-glucoside (vicenin-2) \\
\hline 80 & 28.3 & 270,338 & 547 & Apigenin-C-rhamnosyl arabinoside \\
\hline 81 & 28.8 & 270,340 & 563.5 & Apigenin-6-C-glucosyl-8-C-arabinose (isoschaftoside) \\
\hline 82 & 29.3 & 270,340 & 415.4 & Apigenin- $C$-rhamnoside \\
\hline 83 & 29.6 & 270,338 & 461 & Luteolin-O-glucuronide \\
\hline 84 & 33.6 & 300,330 & 515.4 & Dicaffeoylquinic acid \\
\hline 85 & 35.8 & 330,300 & 315 & Caffeic acid-dihydroxy phenyl ethyl ester \\
\hline 86 & 36 & 300,330 & 515.8 & Dicaffeoylquinic acid \\
\hline 87 & 37.2 & 330,300 & 515 & Dicaffeoylquinic acid \\
\hline 88 & 38.6 & 270,340 & 563.6 & Apigenin-8-C-glucosyl-6- $C$-arabinose (schaftoside) \\
\hline 89 & 41.4 & 270,340 & 609.4 & Luteolin-6,8-di- $C$-glucoside (lucenin-2) \\
\hline 90 & 42.7 & 270,340 & 579.3 & Pentosyl orientin \\
\hline 91 & 42.8 & 270,340 & 431 & Vitexin \\
\hline 92 & 44.3 & ND & 463.3 & Quercetin-O-glucoside \\
\hline 93 & 45.8 & ND & 515.3 & Dicaffeoylquinic acid \\
\hline 94 & 48.4 & 330,300 & 375.1 & Ferulic acid-methoxy trihydroxy phenyl ethyl ester \\
\hline 95 & 49.1 & 310 & 231.2 & Hydroxy-prenylcinnamic acid \\
\hline 96 & 49.8 & 310 & 315.4 & 3-Prenyl-4-(2-methylpropionyloxy)-cinnamic acid methyl ester \\
\hline 97 & 52.3 & 270,340 & 489.8 & Luteolin acetylglucoside \\
\hline 98 & 52.5 & 270,340 & 461.2 & Chrysoeriol-C-glucoside \\
\hline 99 & 53.1 & 280 & 623.4 & Dimethoxy naringenin-diglucoside \\
\hline 100 & 53.8 & 300,330 & 529.7 & Caffeoylferuloylquinic acid \\
\hline 101 & 54.1 & 270,340 & 593.3 & Apigenin-di-O-glucoside \\
\hline 102 & 54.6 & 256,356 & 433 & Quercetin-O-arabinoside \\
\hline
\end{tabular}


TABLE 3: Continued.

\begin{tabular}{|c|c|c|c|c|}
\hline Compound & Rt (min) & $\mathrm{UV} / \mathrm{DAD}$ & {$[\mathrm{M}-\mathrm{H}]^{-}$} & Proposed structure \\
\hline 103 & 55.5 & 260,355 & 447.1 & Quercetin-O-rhamnoside \\
\hline 104 & 56.3 & 300,330 & 515.9 & Dicaffeoylquinic acid \\
\hline 105 & 56.6 & 260,350 & 477.1 & Isorhamnetin-glucoside \\
\hline 106 & 58.8 & 300,330 & 677.4 & Tricaffeoylquinic acid \\
\hline 107 & 59.8 & 330,300 & 677.3 & Tricaffeoylquinic acid \\
\hline 108 & 60.4 & 270,335 & 445.1 & Apigenin-O-glucuronide \\
\hline 109 & 60.5 & ND & 389.3 & Diprenyl chrysin \\
\hline 110 & 60.6 & 330 & 329 & Ferulic acid dihydroxy phenyl ethyl ester \\
\hline 111 & 65.9 & 260,353 & 301.2 & Quercetin \\
\hline 112 & 66 & ND & 309.1 & Cinnamoyl hexoside \\
\hline 113 & 66.5 & 330,300 & 529.6 & Caffeoylferuloylquinic acid \\
\hline 114 & 67.9 & 256,356 & 315.1 & Isorhamnetin \\
\hline 115 & 70.6 & 256,356 & 315.1 & Rhamnetin \\
\hline 116 & 71.2 & 255,354 & 331 & Laricitin \\
\hline 117 & 72.1 & 310 & 315.5 & 3-Hydroxy-2,2-dimethyl-8-prenylchromane-6-propenoic acid \\
\hline 118 & 72.3 & 230,350 & 299.1 & Methyl licochalcone B \\
\hline 119 & 73 & 310 & 299 & Hydroxy-diprenylcinnamic acid (artepillin C) \\
\hline 120 & 73.9 & 256,356 & 329.1 & Quercetin-dimethyl ether \\
\hline 121 & 74.2 & ND & 387.4 & Pentamethoxy hydroxy flavonol \\
\hline 122 & 76.9 & ND & 371.6 & Pentamethoxy flavonol \\
\hline 123 & 78 & ND & 401.2 & Nobiletin \\
\hline 124 & 79.1 & ND & 399.5 & Chrysin rhamnoside \\
\hline 125 & 82.1 & ND & 395.2 & Prenyl-trimethoxyluteolin \\
\hline 126 & 83.2 & 255,355 & 383.4 & Prenyl-methoxyquercetin \\
\hline 127 & 86 & 260,370 & 273.1 & Phloretin \\
\hline 128 & 87.5 & 260,360 & 383.3 & Prenyl-methoxyquercetin \\
\hline 129 & 88.1 & 260,360 & 367.1 & Prenyl-methoxykaempferol \\
\hline 130 & 88.9 & ND & 397.2 & Prenyl-dimethoxyquercetin \\
\hline 131 & 89.9 & 260,355 & 381.2 & Prenyl-dimethoxykaempferol \\
\hline 132 & 91.1 & 260,350 & 381.8 & Prenyl-dimethoxykaempferol \\
\hline 133 & 93.1 & 260,360 & 395.2 & Prenyl-trimethoxykaempferol \\
\hline
\end{tabular}

regions, derived from exudates from the vegetative buds of Populus spp. [19, 55]. However, flavonoids commonly detected in propolis are aglycones, and only rare flavonoid glycosides have been reported as propolis constituents.

The samples from Pariquera-Açu (SP, southeast) and Ponta Grossa (PR, south) contain also some of these green propolis constituents but emerge at the base of the clustering analysis tree (Figure 2). Both contain substances rarely or never reported for green propolis, such as flavonoid glycosides (e.g., 81, 88, and 97; Table 4). They also contain or share diterpenes, such as $\mathbf{1 7}$ and $\mathbf{2 3}$ (Table 4), a class of substances known to occur in Brazilian propolis $[43,56,57]$ and abundant in Mediterranean propolis $[20,58]$.

The samples from Mira Bela (MG, southeast), Pirenópolis (GO, Central Brazil), and Picos (PI, central-north) constitute another cluster, in spite of the large distances among the localities. The chemical composition of Mira Bela stands out by the total absence of nonpolar constituents from the chloroform extract (Table 4). It is worth noting that triterpenes (42-52; Table 4) were detected only in black propolis

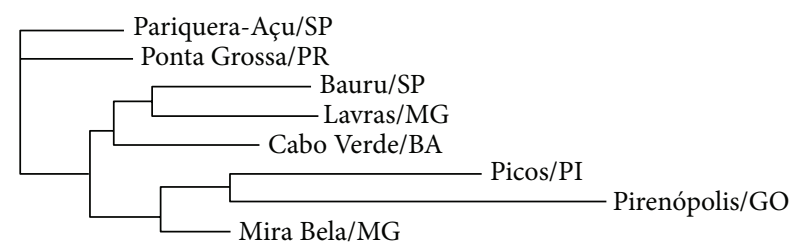

FIGURE 2: Clustering analysis of identified constituents by GC/MS and HPLC/ESI/MS of samples of Brazilian propolis using the neighbor-joining method.

samples (from Picos and Pirenópolis). Besides this, both samples contain, and sometimes share, wax constituents, such as fatty acids (e.g., 32, 34) and $n$-alkanes (e.g., 33, 36, and 37; Table 4). Flavonoids were more often detected in the samples from this cluster. Examples are the aglycones quercetin (111), isorhamnetin (114), and rhamnetin (115; Table 4). In addition, the sample from Mira Bela is characterized for containing flavone $C$-glycosides, such as 77, 79, 80, and 82 (Table 4). 
TABLE 4: Constituents from the chloroform and methanol extracts of samples of Brazilian propolis from the municipalities of Pariquera-Açu (Par; state of São Paulo), Ponta Grossa (PGr; state of Paraná), Bauru (Bau; state of São Paulo), Lavras (Lav; state of Minas Gerais), Cabo Verde (CVe; state of Bahia), Mira Bela (MBe; state of Minas Gerais), Picos (Pic; state of Piauí), and Pirenópolis (Pir; state of Goiás). Compounds are characterized by GC/EIMS and HPLC/ESIMS.

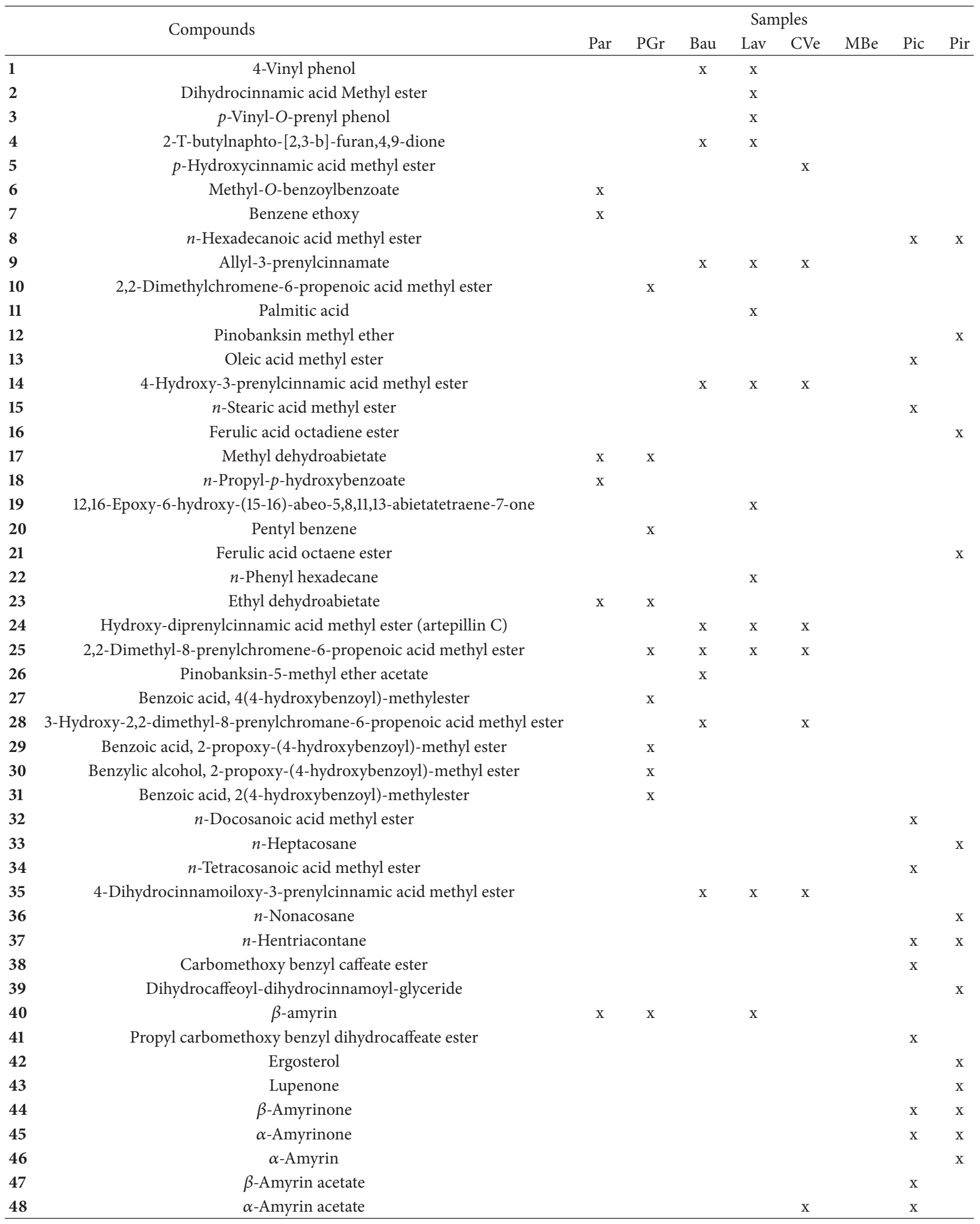


TABle 4: Continued.

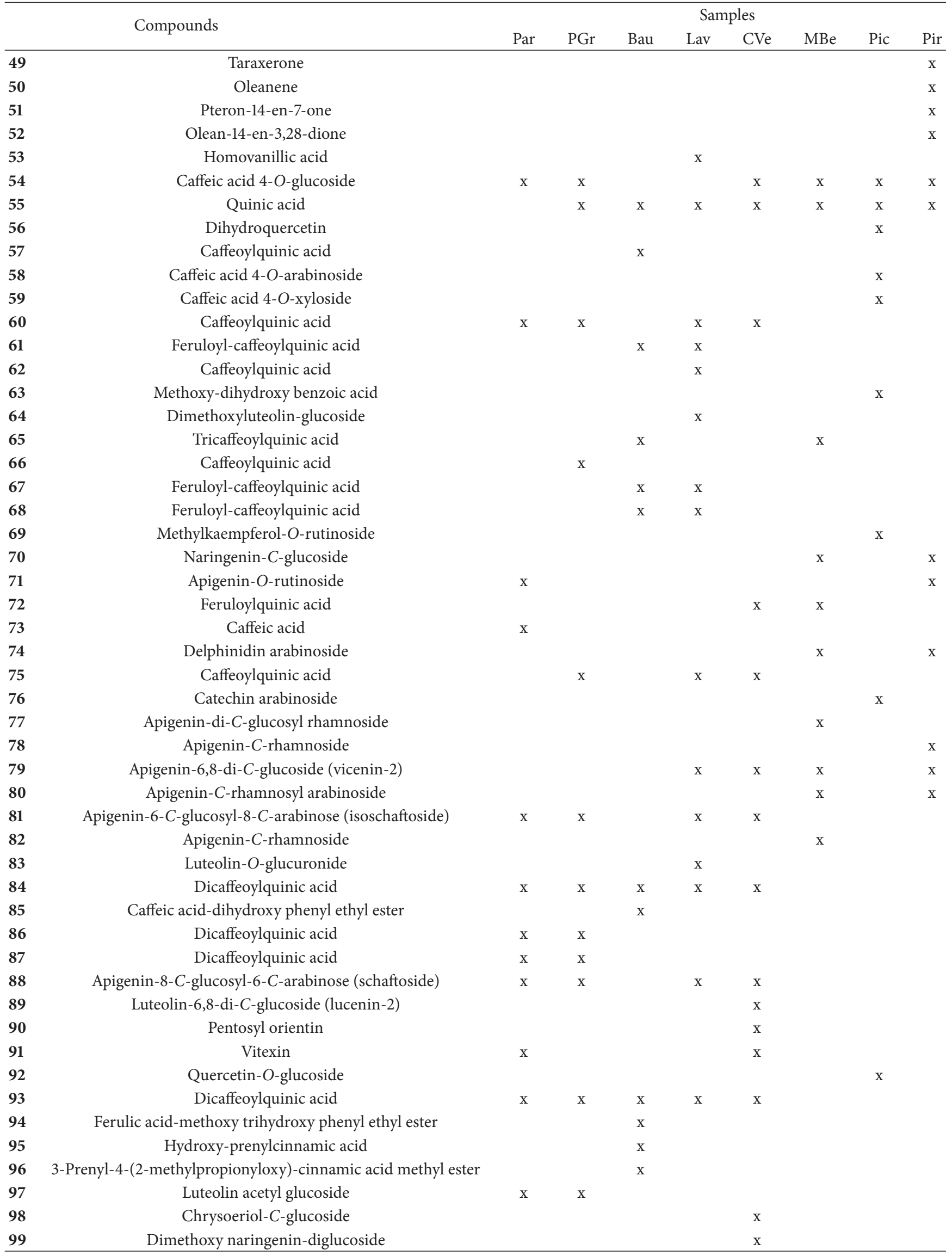


TABLE 4: Continued.

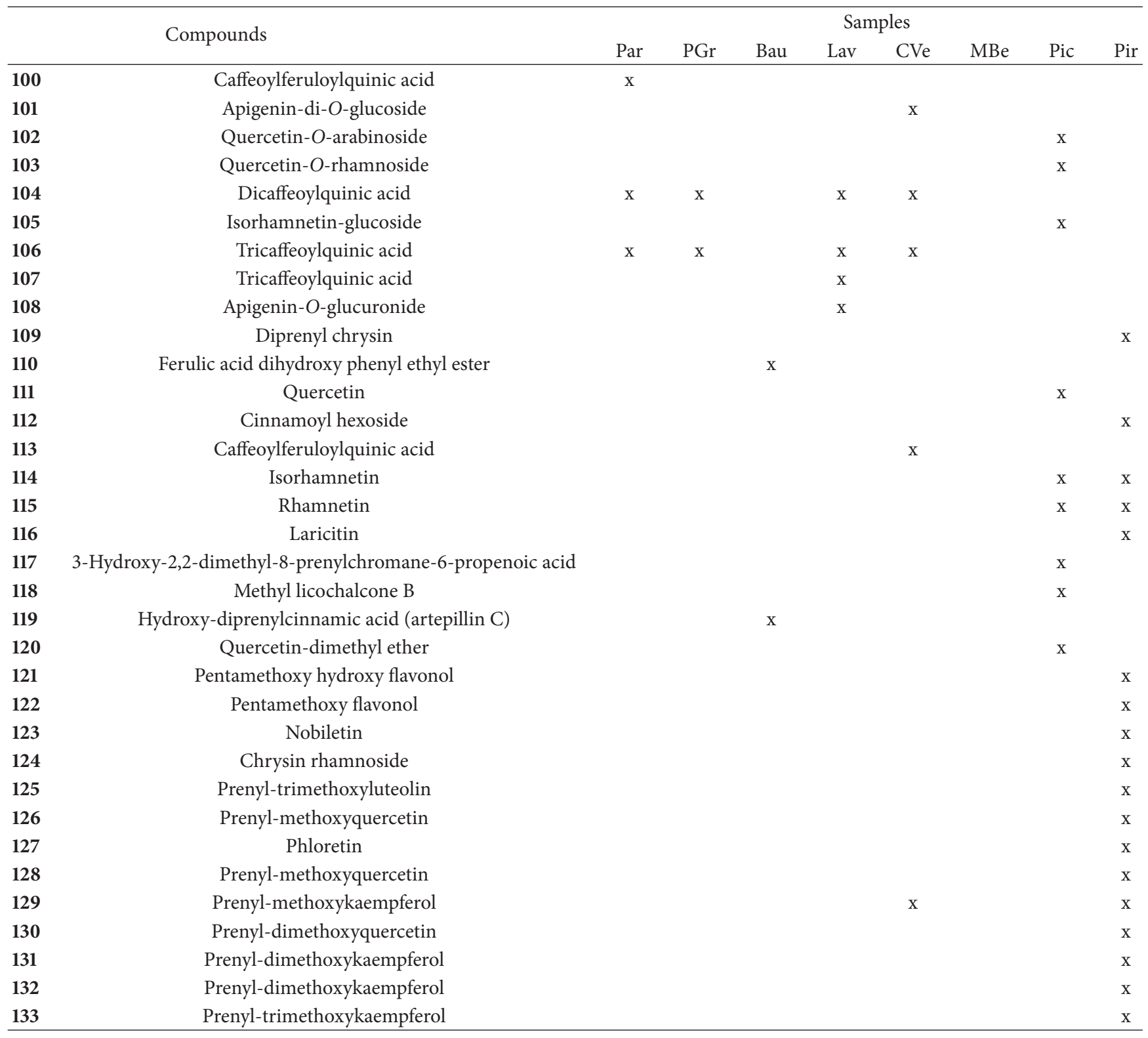

The long branches corresponding to the samples of Picos and chiefly of Pirenópolis indicate a high number of exclusive characteristics. The sample from Picos is particularly characterized by flavonol- $O$-glycosides: $92,102,103$, and 105. A remarkable characteristic of the sample from Pirenópolis is represented by prenylated flavones (109) and flavonols (125, 126, and 128-133; Table 4). The present work is the first report of prenylated flavonoids for Brazilian propolis. Prenylflavonoids are a rare feature in Neo-Tropical propolis but are characteristic in propolis derived from Macaranga spp., having been reported from Okinawa [59] and other localities, such as Egypt and Kenya [12]. Prenylation of aromatic compounds is a chemical feature enhancing biological activities [60]. Another interesting compound from the Pirenópolis sample is the glyceride 39 (Table 4). The frequent detection of flavonoids in the samples from Picos and Pirenópolis is coherent with the high amount of total flavonoids shown in Table 1 .

\section{Conclusions}

Compounds derived from Baccharis dracunculifolia (alecrimdo-campo plant) are often found in Brazilian propolis, despite considerable chemical differences among them. Propolis samples from the typical distributional zone of alecrim-docampo plant (southeast of Brazil) may have little or no chemical affinity at all with green propolis. On the other hand, samples from the northeast of Brazil, such as from Cabo Verde, may have high chemical affinity with green propolis. Analysis of propolis from distinct regions of Brazil is likely to provide chemical substances rarely found in propolis (such 
as flavonoid glycosides) and substances with high biological activity (such as prenylated flavonoids).

\section{Acknowledgments}

The authors are grateful to FAPESP and CNPq for financial support and to Apiários Martins, Breyer and Cia, Mellilotus Ltda, Melnor Wenzel Ltda, and Pronatu Ltda for the supply of propolis samples.

\section{References}

[1] S. R. Lustosa, A. B. Galindo, L. C. C. Nunes, K. P. Randau, and P. J. R. Neto, "Propolis: updates on chemistry and pharmacology," Brazilian Journal of Pharmacognosy, vol. 18, no. 3, pp. 447-454, 2008.

[2] V. Bankova, "Recent trends and important developments in propolis research," Evidence-Based Complementary and Alternative Medicine, vol. 2, no. 1, pp. 29-32, 2005.

[3] S. Z. Yang, L. T. Peng, X. J. Su et al., "Bioassay-guided isolation and identification of antifungal components from propolis against Penicillium italicum," Food Chemistry, vol. 127, no. 1, pp. 210-215, 2011.

[4] G. Vardar-Unlu, S. Silici, and M. Unlu, "Composition and in vitro antimicrobial activity of Populus buds and poplar-type propolis," World Journal of Microbiology and Biotechnology, vol. 24, no. 7, pp. 1011-1017, 2008.

[5] E. M. A. F. Bastos, M. Simone, D. M. Jorge, A. E. E. Soares, and M. Spivak, "In vitro study of the antimicrobial activity of Brazilian propolis against Paenibacillus larvae," Journal of Invertebrate Pathology, vol. 97, no. 3, pp. 273-281, 2008.

[6] N. Paulino, S. R. L. Abreu, Y. Uto et al., "Anti-inflammatory effects of a bioavailable compound, Artepillin C, in Brazilian propolis," European Journal of Pharmacology, vol. 587, no. 1-3, pp. 296-301, 2008.

[7] W. K. Jung, D. Y. Lee, Y. H. Choi et al., "Caffeic acid phenethyl ester attenuates allergic airway inflammation and hyperresponsiveness in murine model of ovalbumin-induced asthma," Life Sciences, vol. 82, no. 13-14, pp. 797-805, 2008.

[8] J. Xi and Z. Shouqin, "Antioxidant activity of ethanolic extracts of propolis by high hydrostatic pressure extraction," International Journal of Food Science and Technology, vol. 42, no. 11, pp. 1350-1356, 2007.

[9] W. M. Wu, L. Lu, Y. Long et al., "Free radical scavenging and antioxidative activities of caffeic acid phenethyl ester (CAPE) and its related compounds in solution and membranes: a structure-activity insight," Food Chemistry, vol. 105, no. 1, pp. 107-115, 2007.

[10] M. P. De Barros, J. P. B. Sousa, J. K. Bastos, and S. F. de Andrade, "Effect of Brazilian green propolis on experimental gastric ulcers in rats," Journal of Ethnopharmacology, vol. 110, no. 3, pp. 567-571, 2007.

[11] N. Orsolic and I. Basic, "Water-soluble derivative of propolis and its polyphenolic compounds enhance tumoricidal activity of macrophages," Journal of Ethnopharmacology, vol. 102, no. 1, pp. 37-45, 2005.

[12] A. Salatino, C. C. Fernandes-Silva, A. A. Righi, and M. L. F. Salatino, "Propolis research and the chemistry of plant products," Natural Product Reports, vol. 28, no. 5, pp. 925-936, 2011.
[13] K. Hrobonova, J. Lehotay, and J. Cizmarik, "Determination of some phenolic acids in propolis by an HPLC method," Journal of Liquid Chromatography and Related Technologies, vol. 31, no. 8, pp. 1213-1226, 2008.

[14] C. Gardana, M. Scaglianti, P. Pietta, and P. Simonetti, "Analysis of the polyphenolic fraction of propolis from different sources by liquid chromatography-tandem mass spectrometry," Journal of Pharmaceutical and Biomedical Analysis, vol. 45, no. 3, pp. 390-399, 2007.

[15] S. Awale, F. Li, H. Onozuka, H. Esumi, Y. Tezuka, and S. Kadota, "Constituents of Brazilian red propolis and their preferential cytotoxic activity against human pancreatic PANC-1 cancer cell line in nutrient-deprived condition," Bioorganic and Medicinal Chemistry, vol. 16, no. 1, pp. 181-189, 2008.

[16] F. Li, S. Awale, Y. Tezuka, and S. Kadota, "Cytotoxic constituents from Brazilian red propolis and their structure-activity relationship," Bioorganic and Medicinal Chemistry, vol. 16, no. 10, pp. 5434-5440, 2008.

[17] N. Sahinler and O. Kaftanoglu, "Natural product propolis: chemical composition," Natural Product Research, vol. 19, no. 2, pp. 183-188, 2005.

[18] A. Abu-Mellal, N. Koolaji, R. K. Duke, V. H. Tran, and C. C. Duke, "Prenylated cinnamate and stilbenes from Kangoroo Island propolis and their antioxidant activity," Phytochemistry, vol. 77, pp. 251-259, 2012.

[19] V. S. Bankova, S. L. de Castro, and M. C. Marcucci, "Propolis: recent advances in chemistry and plant origin," Apidologie, vol. 31, no. 1, pp. 3-15, 2000.

[20] M. P. Popova, K. Graikou, I. Chinou, and V. S. Bankova, "GCMS profiling of diterpene compounds in mediterranean propolis from Greece," Journal of Agricultural and Food Chemistry, vol. 58, no. 5, pp. 3167-3176, 2010.

[21] C.-N. Chen, C.-L. Wu, H.-S. Shy, and J.-K. Lin, "Cytotoxic prenylflavanones from Taiwanese propolis," Journal of Natural Products, vol. 66, no. 4, pp. 503-506, 2003.

[22] S. Kumazawa, H. Goto, T. Hamasaka, S. Fukumoto, T. Fujimoto, and T. Nakayama, "A new prenylated flavonoid from propolis collected in Okinawa, Japan," Bioscience, Biotechnology and Biochemistry, vol. 68, no. 1, pp. 260-262, 2004.

[23] M. P. Popova, I. B. Chinou, I. N. Marekov, and V. S. Bankova, "Terpenes with antimicrobial activity from Cretan propolis," Phytochemistry, vol. 70, no. 10, pp. 1262-1271, 2009.

[24] E. W. Teixeira, D. Message, G. Negri, A. Salatino, and P. C. Stringheta, "Seasonal variation, chemical composition and antioxidant activity of brazilian propolis samples," EvidenceBased Complementary and Alternative Medicine, vol. 7, no. 3, pp. 307-315, 2010.

[25] B. Trusheva, M. Popova, V. Bankova et al., "Bioactive constituents of Brazilian red propolis," Evidence-Based Complementary and Alternative Medicine, vol. 3, no. 2, pp. 249-254, 2006.

[26] A. A. Righi, T. R. Alves, G. Negri, L. M. Marques, H. Breyer, and A. Salatino, "Brazilian Red Propolis: unreported substances, antioxidant and antimicrobial activities," Journal of the Science of Food and Agriculture, vol. 91, no. 13, pp. 2363-2370, 2011.

[27] V. F. C. Ishida, G. Negri, A. Salatino, and M. F. C. L. Bandeira, "A new type of Brazilian propolis: prenylated benzophenones in propolis from Amazon and effects against cariogenic bacteria," Food Chemistry, vol. 125, no. 3, pp. 966-972, 2011.

[28] A. Salatino, E. W. Teixeira, G. Negri, and D. Message, "Origin and chemical variation of Brazilian propolis," Evidence-based Complementary and Alternative Medicine, vol. 2, no. 1, pp. 3338, 2005. 
[29] K. Sorkun, B. Suer, and B. Salih, "Determination of chemical composition of Turkish propolis," Zeitschrift fur Naturforschung C, vol. 56, no. 7-8, pp. 666-668, 2001.

[30] V. Bankova, M. Popova, S. Bogdanov, and A. G. Sabatini, "Chemical composition of European propolis: expected and unexpected results," Zeitschrift fur Naturforschung C, vol. 57, no. 5-6, pp. 530-533, 2002.

[31] G. Negri, M. L. F. Salatino, and A. Salatino, "Green propolis': unreported constituents and a novel compound from chloroform extracts," Journal of Apicultural Research, vol. 42, no. 3, pp. 39-41, 2003.

[32] G. Negri, M. L. F. Salatino, and A. Salatino, "Unusual chemical composition of a sample of Brazilian propolis, as assessed by analysis of a chloroform extract," Journal of Apicultural Research, vol. 42, no. 4, pp. 53-56, 2003.

[33] M. C. Marcucci, J. Rodriguez, F. Ferreres, V. Bankova, R. Groto, and S. Popov, "Chemical composition of Brazilian propolis from Sao Paulo State," Zeitschrift fur Naturforschung C, vol. 53, no. 1-2, pp. 117-119, 1998.

[34] E. W. Teixeira, D. Message, G. Negri, A. Salatino, and P. C. Stringheta, "Seasonal variation, chemical composition and antioxidant activity of Brazilian propolis samples," EvidenceBased Complementary and Alternative Medicine, vol. 7, no. 3, pp. 307-315, 2010.

[35] A. L. Piccinelli, C. Lotti, L. Campone, O. Cuesta-Rubio, M. C. Fernandez, and L. Rastrelli, "Cuban and Brazilian red propolis: botanical origin and comparative analysis by high-performance liquid chromatography-photodiode array detection/ electrospray ionization tandem mass spectrometry," Journal of Agricultural and Food Chemistry, vol. 59, no. 12, pp. 6484-6491, 2011.

[36] G. Negri, M. C. Marcucci, A. Salatino, and M. L. F. Salatino, "Comb and propolis waxes from Brazil (States of São Paulo and Paraná)," Journal of the Brazilian Chemical Society, vol. 11, no. 5, pp. 453-457, 2000.

[37] R. G. Woisky and A. Salatino, "Analysis of propolis: some parameters and procedures for chemical quality control," Journal of Apicultural Research, vol. 37, no. 2, pp. 99-105, 1998.

[38] M. Nagy and D. Grančai, "Colorimetric determination of flavanones in propolis," Pharmazie, vol. 51, no. 2, pp. 100-101, 1996.

[39] S. W. MacLafferty and D. B. Stauffer, The Wiley/NBS Registry of Mass Espectral Data, John Wiley, New York, NY, USA, 1989.

[40] Swofford DL. PAUP*: Phylogenetic Analysis Using Parsimony ( ${ }^{*}$ other methods), version 4.0b10. Sinauer Associates, Sunderland, Mass, USA, 2002.

[41] A. R. Custodio, M. M. C. Ferreira, G. Negri, and A. Salatino, "Clustering of comb and propolis waxes based on the distribution of aliphatic constituents," Journal of the Brazilian Chemical Society, vol. 14, no. 3, pp. 354-357, 2003.

[42] E. W. Teixeira, G. Negri, R. M. S. A. Meira, D. Message, and A. Salatino, "Plant origin of green propolis: bee behavior, plant anatomy and chemistry," Evidence-Based Complementary and Alternative Medicine, vol. 2, no. 1, pp. 85-92, 2005.

[43] V. Bankova, M. C. Marcucci, S. Simova, N. Nikolova, A. Kujumgiev, and S. Popov, "Antibacterial diterpenic acids from Brazilian propolis," Zeitschrift fur Naturforschung C, vol. 51, no. 5-6, pp. 277-280, 1996.

[44] F. Li, S. Awale, Y. Tezuka, H. Esumi, and S. Kadota, "Study on the constituents of mexican propolis and their cytotoxic activity against PANC-1 human pancreatic cancer cells," Journal of Natural Products, vol. 73, no. 4, pp. 623-627, 2010.
[45] S. A. L. Moura, G. Negri, A. Salatino et al., "Aqueous extract of Brazilian Green Propolis: primary components, evaluation of inflammation and wound healing by using subcutaneous implanted sponges," Evidence-Based Complementary and Alternative Medicine, vol. 2011, Article ID 748283, 8 pages, 2011.

[46] T. Takemura, T. Urushisaki, M. Fukuoka et al., "3,4Dicaffeoylquinic acid, a major constituent of Brazilian propolis, increases TRAIL expression and extends the lifetime of mica infected with influenza virus," Evidence-Based Complementary and Alternative Medicine, vol. 2012, Article ID 946867, 7 pages, 2012.

[47] P. Truchado, P. Vit, F. Ferreres, and F. Tomas-Barberan, "Liquid chromatography tandem mass spectrometry analysis allows the simultaneous characterization of C-glycosyl and O-glycosyl flavonoids in stingless bee honeys," Journal of Chromatography A, vol. 1218, pp. 7601-7607, 2011.

[48] P. Truchado, F. Ferreres, and F. A. Tomas-Barberan, "Liquid chromatography-tandem mass spectrometry reveals the widespread occurrence of flavonoid glycosides in honey, and their potential as floral origin markers," Journal of Chromatography $A$, vol. 1216, no. 43, pp. 7241-7248, 2009.

[49] A. L. Piccinelli, M. G. Mesa, D. M. Armenteros et al., "HPLCPDA-MS and NMR characterization of C-glycosyl flavones in a hydroalcoholic extract of Citrus aurantifolia leaves with antiplatelet activity," Journal of Agricultural and Food Chemistry, vol. 56, no. 5, pp. 1574-1581, 2008.

[50] D. Barreca, E. Bellocco, C. Caristi, U. Leuzzi, and G. Gattuso, "Flavonoid profile and radical-scavenging activity of Mediterranean sweet lemon (Citrus limetta Risso) juice," Food Chemistry, vol. 129, no. 2, pp. 417-422, 2011.

[51] A. Figueirinha, A. Paranhos, J. J. Pérez-Alonso, C. SantosBuelga, and M. T. Batista, "Cymbopogon citratus leaves: characterization of flavonoids by HPLC-PDA-ESI/MS/MS and an approach to their potential as a source of bioactive polyphenols," Food Chemistry, vol. 110, no. 3, pp. 718-728, 2008.

[52] B. Abad-García, L. A. Berrueta, S. Garmón-Lobato, B. Gallo, and F. Vicente, "A general analytical strategy for the characterization of phenolic compounds in fruit juices by highperformance liquid chromatography with diode array detection coupled to electrospray ionization and triple quadrupole mass spectrometry," Journal of Chromatography A, vol. 1216, no. 28, pp. 5398-5415, 2009.

[53] F. Ferreres, C. Sousa, P. Valentao, P. B. Andrade, R. M. Seabra, and A. Gil-Izquierdo, "New C-deoxyhexosyl flavones and antioxidant properties of Passiflora edulis leaf extract," Journal of Agricultural and Food Chemistry, vol. 55, no. 25, pp. 1018710193, 2007.

[54] J. D. Djoukeng, V. Arbona, R. Argamasilla, and A. GomezCadenas, "Flavonoid profiling in leaves of citrus genotypes under different environmental situations," Journal of Agricultural and Food Chemistry, vol. 56, no. 23, pp. 11087-11097, 2008.

[55] M. C. Marcucci, "Propolis: chemical composition, biological properties and therapeutic activity," Apidologie, vol. 26, no. 2, pp. 83-99, 1995.

[56] A. H. Banskota, Y. Tezuka, J. K. Prasain, K. Matsushige, I. Saiki, and S. Kadota, "Chemical constituents of Brazilian propolis and their cytotoxic activities," Journal of Natural Products, vol. 61, no. 7, pp. 896-900, 1998.

[57] A. H. Banskota, Y. Tezuka, I. K. Adnyana et al., "Hepatoprotective and anti-Helicobacter pylori activities of constituents from Brazilian propolis," Phytomedicine, vol. 8, no. 1, pp. 16-23, 2001. 
[58] M. Popova, B. Trusheva, D. Antonova et al., "The specific chemical profile of Mediterranean propolis from Malta," Food Chemistry, vol. 126, no. 3, pp. 1431-1435, 2011.

[59] S. Kumazawa, J. Nakamura, M. Murase, M. Miyagawa, M. R. Ahn, and S. Fukumoto, "Plant origin of Okinawan propolis: honeybee behavior observation and phytochemical analysis," Naturwissenschaften, vol. 95, no. 8, pp. 781-786, 2008.

[60] K. Yazaki, K. Sasaki, and Y. Tsurumaru, "Prenylation of aromatic compounds, a key diversification of plant secondary metabolites," Phytochemistry, vol. 70, no. 15-16, pp. 1739-1745, 2009. 


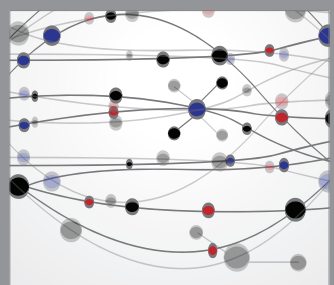

The Scientific World Journal
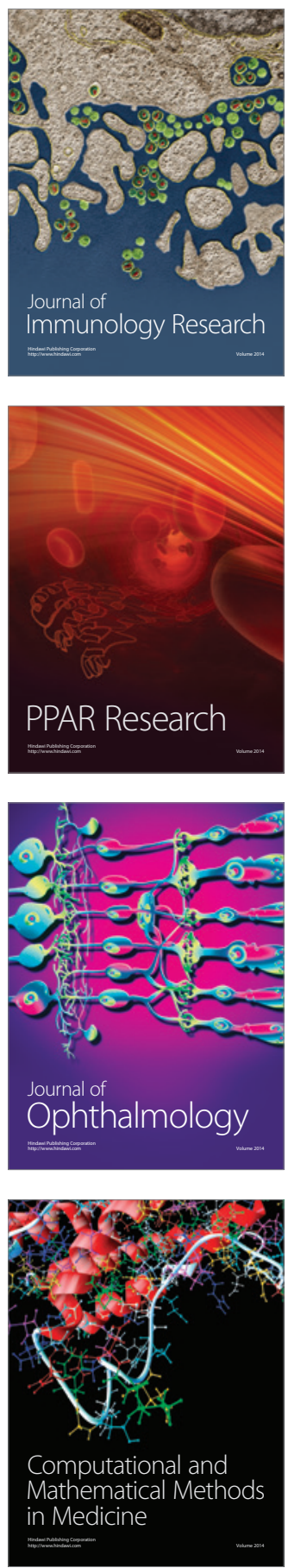

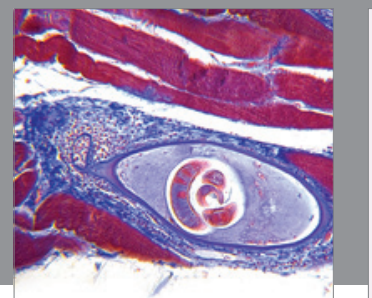

Gastroenterology

Research and Practice
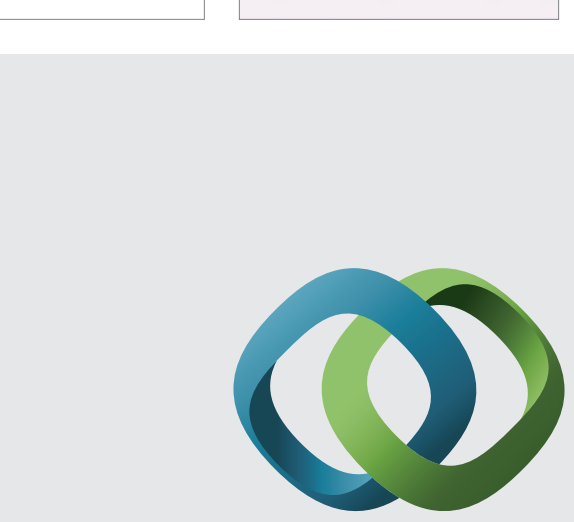

\section{Hindawi}

Submit your manuscripts at

http://www.hindawi.com
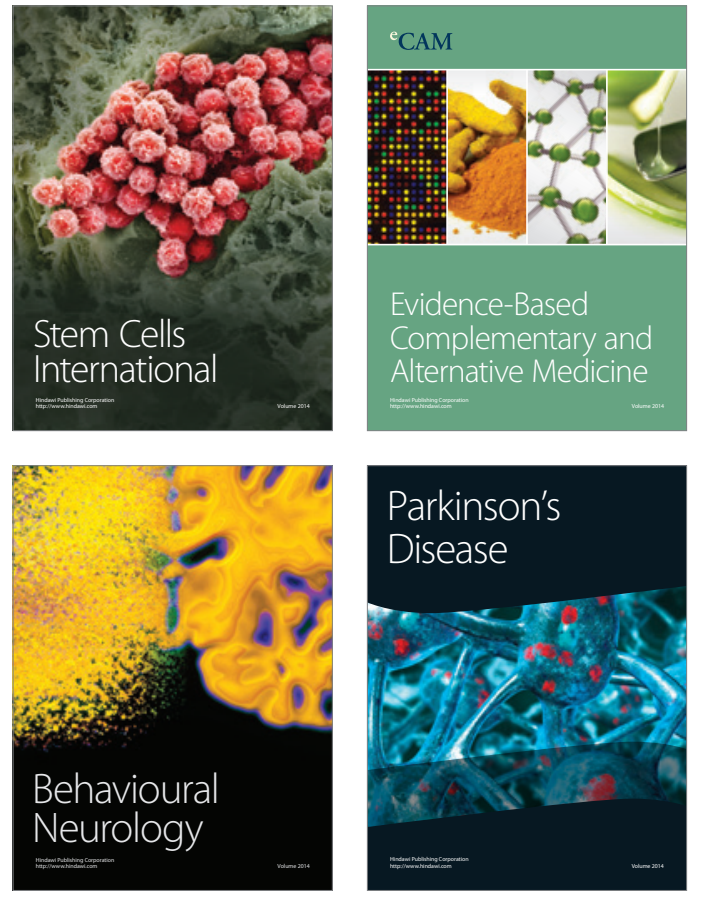
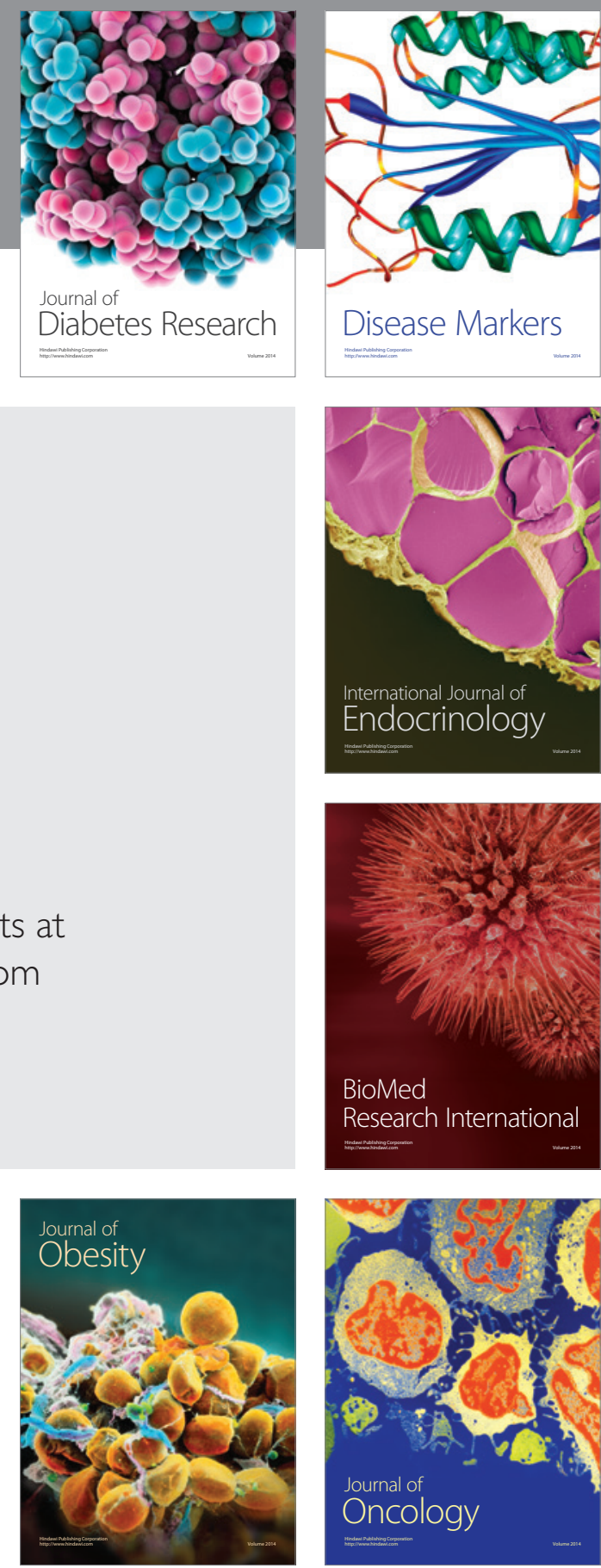

Disease Markers
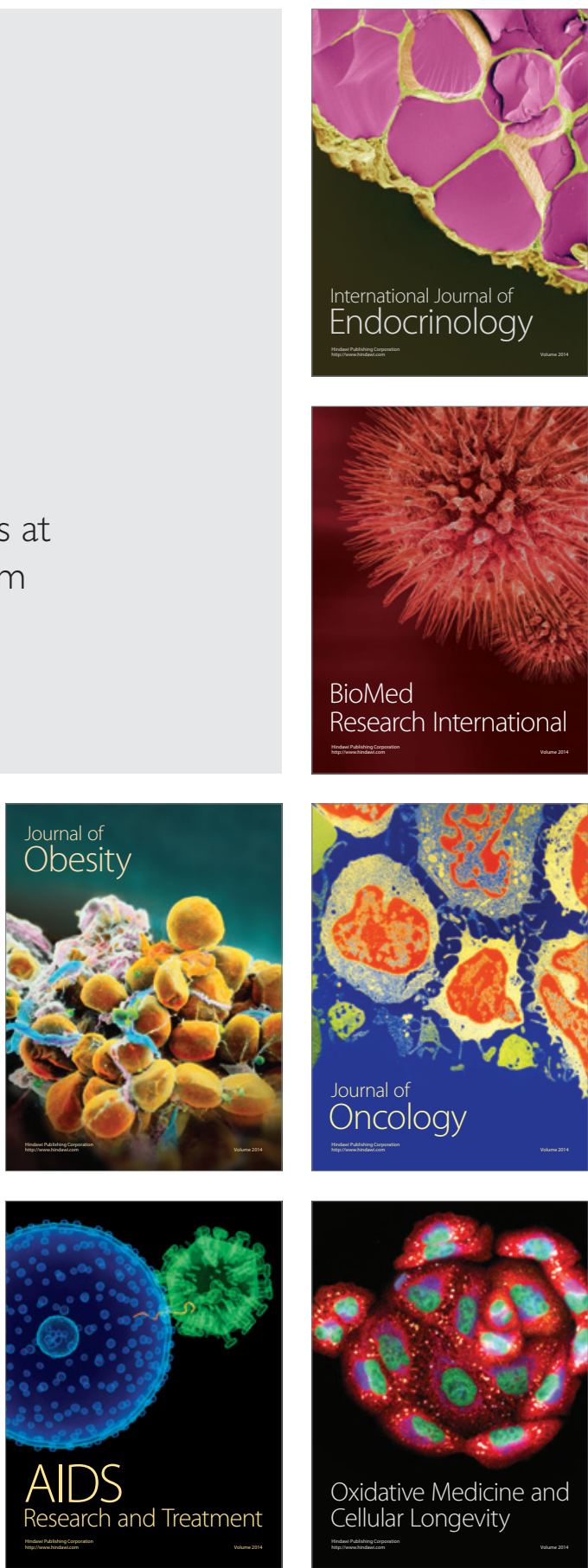